\title{
TARTALÉK ALKATRÉSZSZÁM MEGHATÁROZÁS SZIMULÁCIÓS ÜZEMELTETÉSI RENDSZERELEMZÉSSEL
}

\section{DETERMINATION OF RESERVE PART'S NUMBER BY SIMULATION-BASED MAINTENANCE SYSTEM ANALYSIS}

\author{
Pokorádi László ${ }^{1}$, Fenyvesi Csaba ${ }^{2}$ \\ ${ }^{1}$ Óbudai Egyetem, Mechatronikai és Jármütechnikai Intézet, \\ 1081 Magyarország, Budapest, Népszínház utca, 8. +363099194929, \\ pokoradi.laszlo@bgk.uni-obuda.hu \\ ${ }^{2}$ Óbudai Egyetem, Biztonságtudományi Doktori Iskola, \\ 1081 Magyarország, Budapest, Népszinház utca,8., fenyvesic@npp.hu
}

\begin{abstract}
From the mathematical point of view, the operation of technical systems and equipment is a discrete state space stochastic process without after-effects, so it can be approximated with a Markov-chain. After setting up the transition probability matrix, matrix-algebraic tools can be used for investigating these processes with systems approach analysis. This paper is aimed to discuss the possibilities of the use of Markov matrix-based Monte Carlo Simulation of maintenance processes. The proposed simulation method can be used for the assessment of requested number for spare part depending on required estimating uncertainty.
\end{abstract}

Keywords: maintenance, Monte Carlo simulation, number for spare part

\section{Összefoglalás}

Matematikai szempontból az üzemeltetés egy diszkrét állapotterü, utóhatásmentes sztochasztikus folyamat, így azt Markov-lánccal lehet matematikailag leírni. Az üzemeltetési rendszer sztochasztikus modelljének felállítása után a vizsgált folyamatot rendszerszemléletű megközelítéssel tudjuk elemezni. Monte-Carlo módszernek nevezzük a matematikai modellek megoldásának véletlen mennyiségeket felhasználó numerikus eljárásait, és azok jellemzőinek statisztikus értékelését. Jelen tanulmány bemutatja egy eszközpark szükséges tartalékberendezés-számának megfelelő kockázattal, azaz üzemeltetési biztonsággal történő Monte-Carlo-szimulációs becslési eljárását.

Kulcsszavak: üzemeltetés, Monte-Carlo-szimuláció, tartalék alkatrészek száma

\section{Bevezetés}

A gyakorlati mérnöki munkák egyik legfőbb területe a különböző (gyártó vagy szolgáltató) technikai eszközök, rendszerek és létesítmények üzemeltetése, karbantartása [6]. Tágabb értelmezés esetén az üzemeltetés a technikai eszközök használata, különböző szintű kiszolgálása és javítása által alkotott technikai folyamat. Ez a valós, technikai folyamat matematikai szempont- ból utóhatásmentes, sztochasztikus (úgynevezett Markov) folyamat. Egy adott üzemeltetési folyamat vagy rendszer folytonos idejü, diszkrét állapotterü markovi- vagy fél-markovi folyamatként (azaz láncként) modellezhető és megfelelő statisztikai adatok birtokában elemezhetö [4].

Beállt üzemeltetési folyamaton olyan folyamatot értünk, ahol a különféle állapotváltási - föleg a meghibásodási - valószínüségek időben nem (vagy csak elhanya- 
golható mértékben) változnak. Ilyen üzemeltetési folyamatot tapasztalhatunk a bejáratási és a kiöregedési szakaszok között, ha nem lép fel jelentős változás az üzemeltetési körülményekben [5].

A technikai rendszerek üzemeltetése esetén bizonytalan paraméterek lehetnek a meghibásodási, valamint javítási idők. Ezen időket általánosságban a meghibásodások közti átlagidővel (MTBF - Mean Time Between Failures), illetve az átlagos javítási idővel (MTTR - Mean Time to Repair), vagy az átlagos megfordulási idővel (MRTT - Mean Repair Turnaround Time) jellemeznek.

Az üzemeltetési folyamatok valószínűségi modellezéséhez szükséges matematikai alapismeretek, többek közt, Bharucha-Reid [1], Karlin és Taylor [2], Wentzel és Ovcsarov [7], valamint Pokorádi [4] könyveiben olvashatóak.

Pokorádi a Markov-mátrix alkalmazási lehetőségét mutatja be beállt, azaz stacioner, üzemeltetési folyamat sztochasztikus matematikai modelljének felállítására [3]. A leírt eljárás előnye a könnyü algoritmizálhatóság, mely a Szerző munkájának egyik legfőbb célja.

A Monte-Carlo-módszer egy igen széles körben (az alaptudományoktól a bonyolult rendszerek kockázatanalízisén át a pénzügyi életig) alkalmazott eljárás, amely a vizsgált rendszer vagy folyamat bemenő jellemzőinek véletlen generálásán alapul. Egy technikai rendszer vagy folyamat - és így matematikai modelljének - bemenő jellemzői gyakran valamilyen valószínüségi eloszlásokkal jellemezhetőek. Ha ismerjük ezeket az eloszlásokat, a Monte-Carlo-szimuláció véletlen mintavételezéssel végezhető el.

Egy üzemeltetési folyamat irányításához, a megfelelő rendszerszintü üzemképesség fenntartásához a döntéshozók által elvárt pontossággal tudnunk kell a szükséges tartalékberendezések számát.

A tanulmány célja - a fentiekben ismertetett tudományos munkákra támaszkodva - a beállt üzemeltetési folyamatok stacioner Markov-modelljére épülő Monte-Carloszimuláció alkalmazásával kidolgozott elemzési eljárás bemutatása. A leírt módszer alkalmas a megfelelö, vagy elvárt szintű üzemképesség fenntartásához szükséges tartalékberendezések számának meghatározására.

A tanulmány az alábbi részekből áll: A 2. fejezet a vizsgált üzemeltetési rendszer matematikai modelljét írja le röviden. A 3. fejezetben a rendszer Monte-Carlo szimulációs vizsgálatát találjuk meg. A 4 . fejezet a kapott eredmények szakmai kiértékelését mutatja be. Végül az 5. fejezet összegzi a tanulmány elkészítésekor szerzett tapasztalatokat.

\section{A folyamatmodell}

Egy nagyméretü hálózati rendszeren belül tömegesen alkalmazott berendezés üzemeltetése során négy $(\boldsymbol{A} ; \boldsymbol{B} ; \boldsymbol{C} ; \boldsymbol{D})$ eltérö típusú - egy-egy részegységéhez kötődő meghibásodást tapasztaltak. A berendezés javításának sajátossága, hogy - a $C$ típusú meghibásodás kivételével - jelentős méretü (mintegy másfél hónapos) logisztikai időigényt is jelent.

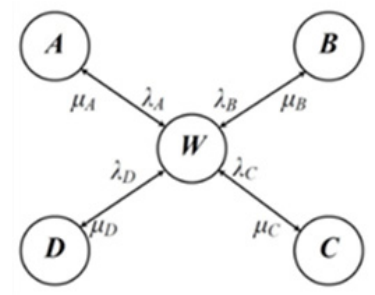

1. ábra. A folyamat gráf modellje

$W$ - rendelkezésre állás;

A - A típusú meghibásodás javitása;

$B-B$ típusú meghibásodás javitása;

$C-C$ típusú meghibásodás javitása;

D-D típusú meghibásodás javitása

Mivel vizsgálatunkat alapvetően a végfelhasználó szempontjából végeztük, így a javításhoz kötődő oda-vissza történő szállítást is a javításokhoz kötöttük, azaz a javítás 
időigényét az úgynevezett átlagos megfordulási idővel jellemezzük. Továbbá az is megállapítható volt, hogy a meghibásodások esetén a berendezés helyszíni cseréjének ideje elhanyagolható a meghibásodások közti, illetve megfordulási időkhöz képest. Így ezen időigényektől a modellalkotás során eltekintünk.

A meghibásodások és azok javítási idejeinek főbb statisztikai adatait az 1. táblázat tartalmazza. A folyamatot az 1. ábrán látható súlyozott élü, irányított gráffal szemléltetjük, ahol az élek súlyát az állapotváltási valószínűség sürüségek (meghibásodási, illetve megfordulási ráták) adják meg.

1. táblázat. Statisztikai elemzés föbb adatai

\begin{tabular}{|c|c|c|c|c|}
\hline & $\begin{array}{c}\text { MTBF } \\
{[\text { óra] }}\end{array}$ & $\begin{array}{c}\lambda \\
\text { [óra- }^{-1} \text { ] }\end{array}$ & $\begin{array}{c}\text { MRTT } \\
{[\text { óra] }}\end{array}$ & $\begin{array}{c}\mu \\
\text { [óra- }]^{-1}\end{array}$ \\
\hline $\boldsymbol{A}$ & 183627 & $5,446 \cdot 10^{-6}$ & 1080,8 & $9,252 \cdot 10^{-4}$ \\
\hline $\boldsymbol{B}$ & 162059 & $6,171 \cdot 10^{-6}$ & 1081,1 & $9,250 \cdot 10^{-4}$ \\
\hline $\boldsymbol{C}$ & 152800 & $6,545 \cdot 10^{-6}$ & 167,13 & $5,983 \cdot 10^{-3}$ \\
\hline $\boldsymbol{D}$ & 179789 & $5,562 \cdot 10^{-6}$ & 1079,8 & $9,261 \cdot 10^{-4}$ \\
\hline
\end{tabular}

A vizsgált állandósult üzemeltetései folyamat sztochasztikus modellje az alábbi a Szerző [3] tanulmányában részletesen levezetett - mátrixalakban írható fel:

\begin{tabular}{|c|c|c|c|c|c|c|}
\hline$-\left(\lambda_{A}+\lambda_{B}+\lambda_{C}+\lambda_{D}\right)$ & $\mu_{A}$ & $\mu_{B}$ & $\mu_{C}$ & $\mu_{D}$ & 1 & {$\left[P_{W}\right.$} \\
\hline$\lambda_{A}$ & $-\mu_{A}$ & 0 & 0 & 0 & 1 & $P_{A}$ \\
\hline$\lambda_{B}$ & 0 & $-\mu_{B}$ & 0 & 0 & 1 & $P_{B}$ \\
\hline$\lambda_{C}$ & 0 & 0 & $-\mu_{C}$ & 0 & 1 & $P_{C}$ \\
\hline$\lambda_{D}$ & 0 & 0 & 0 & $-\mu_{D}$ & 1 & $P_{D}$ \\
\hline 1 & 1 & 1 & 1 & 1 & 0 & 1 \\
\hline
\end{tabular}

\section{A szimuláció futtatása}

A 2. táblázatban megadott gerjesztéseket alkalmazva futtattuk le az (1) mátrixegyenlettel leírt sztochasztikus modellt.

A korábbi Monte-Carlo szimulációknál szerzett tapasztalatok alapján a gerjesztések számát 2000-ben határoztuk meg. Ez a gerjesztés szám már statisztikailag elegendő adatot szolgáltat, így korrekt szakmai következtetéseket vonhatunk le a kapott futtatási eredményekböl. Az eredmények közül a 2. ábra szemlélteti a - jelen vizsgálatunk szempontjából fontos $-P_{w}$ üzemképességi valószínüségek hisztogramját, illetve 3 táblázatban olvashatóak a statisztikai elemzésük föbb adatai.

2. táblázat. Kiinduló szimulációs adatok statisztikai elemzésének eredményei

\begin{tabular}{|c|c|c|c|c|}
\hline & $\begin{array}{c}\text { MTBF } \\
\text { [óra] }\end{array}$ & $\begin{array}{c}\text { szórás } \\
\text { [óra] }\end{array}$ & $\begin{array}{c}\text { MRTT } \\
\text { [óra] }\end{array}$ & $\begin{array}{c}\text { szórás } \\
\text { [óra] }\end{array}$ \\
\hline A & 183627 & 2033 & 1080,8 & 23,9 \\
\hline B & 162059 & 1881 & 1081,1 & 23,7 \\
\hline C & 152800 & 1659 & 167,13 & 23,16 \\
\hline D & 179789 & 2198 & 1079,8 & 24,3 \\
\hline
\end{tabular}

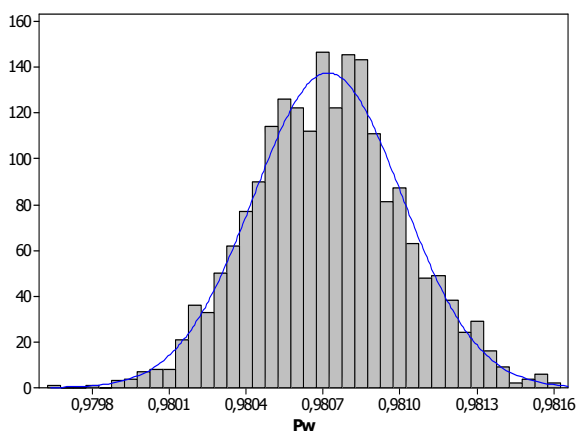

2. ábra. Az üzemképességi valószinüségek hisztogramja

3. táblázat. $A z$ üzemképességi valószinüségek statisztikai elemzésének föbb adatai

\begin{tabular}{|c|c|}
\hline Átlag $m_{W}$ & $9,81 \cdot 10^{-1}$ \\
\hline Minimum & $2,91 \cdot 10^{-4}$ \\
\hline Maximum & $9,80 \cdot 10^{-1}$ \\
\hline Szórás $s_{W}$ & $9,82 \cdot 10^{-1}$ \\
\hline
\end{tabular}

\section{A szükséges tartalékberendezé- sek számának meghatározása}

Vizsgálatunkat alapvetően az üzemeltető szempontjából végeztük el. Így számunkra a legfontosabb kérdés a tartalékberendezések szükséges számának ismerete. 
Ezért az 3. táblázat adatai - a szimulációs eredmények valószínüségi eloszlása alapján meg kell határoznunk mely $N_{R N S}$ tartalékberendezés szám esetén lesz az üzemeltető által elfogadható $R$ kockázati valószínüségnél kisebb a $P_{W}$ rendelkezésreállás bekövetkezési valószínüsége. Például, 10\%-os becslési kockázat ( $90 \%$ üzemeltetési biztonság) esetén:

$$
P_{R N S}=m_{W}-1.29 s_{W} .
$$

Az $N_{R N S}$ szükséges tartalékberendezés szám meghatározását a berendezés $P_{W}$ rendelkezésre állási valószínüség ismeretében tudjuk elvégezni az alábbi egyenlet segítségével:

$$
N_{R N S}=\left\lceil\left(\frac{1}{P_{W}}-1\right) N\right\rceil
$$

ahol: $N$ a rendszerben müködő berendezések száma (vizsgálatunk során: $N=20000$ ).

Ennek ismeretében határoztuk meg a különböző becslési kockázati értékekhez tartozó szükséges tartalékberendezés számot. Ezen eredményeket tartalmazza a

\section{4. táblázat.}

4. táblázat. Szükséges tartalékberendezés szám a becslési kockázat függvényében

\begin{tabular}{|c|c|c|}
\hline$R$ & $P_{R N S}$ & $N_{R N S}$ \\
\hline $10 \%$ & 0,9803 & 402 \\
\hline $5 \%$ & 0,9802 & 404 \\
\hline $1 \%$ & 0,9800 & 409 \\
\hline $0,1 \%$ & 0,9799 & 411 \\
\hline $0,01 \%$ & 0,9798 & 413 \\
\hline
\end{tabular}

\section{5. Összegzés}

A tanulmány bemutatta egy beállt üzemeltetési folyamatok Markov-mátrixszal leírt stacioner sztochasztikus modellre épülő Monte-Carlo-szimulációs elemzésének egy új módszerét. Az esettanulmány során kapott eredmények alapján kijelenthetö, hogy kidolgozott elemzési eljárás alkalmas a karbantartási rendszer hatékonyságának biztosításához, annak növeléséhez szükséges döntések támogatására. A szimulációs eredmények felhasználhatóak egy technikai rendszer üzemeltetéséhez szükséges tartalékberendezések számának - megfelelő becslési kockázattal, azaz üzemeltetési megbízhatósággal történő - meghatározására.

A Szerző célja az üzemeltetési, karbantartási menedzsment döntéshozatalát támogató további matematikai modellezésen, matematikai szimuláción alapuló folyamat-, és rendszerelemzési eljárások kidolgozása, valamint - esettanulmányok felhasználásával - gyakorlati alkalmazási lehetőségeinek bemutatása.

\section{Szakirodalmi hivatkozások}

[1] Bhrucha-Reid A.T.: Elements of the Theory of Markov Processes and Their Applications, McGraw-Hill, New York, 1960.

[2] Karlin S.; Taylor H.M.: Sztochasztikus folyamatok, Gondolat, Budapest, 1985.

[3] Pokorádi L.: Availability Assessment Based on Stochastic Maintenance Process Modeling, Debreceni Müszaki Közlemények 2013/1, pp 37-46.

[4] Pokorádi L.: Rendszerek és folyamatok modellezése, Campus Kiadó, Debrecen, 2008.

[5] Rohács J.; Simon I.: Repülőgépek üzemeltetési zsebkönyve, Müszaki könyvkiadó, Budapest, 1989.

[6] Szabó J.Z.: Müszaki diagnosztikai módszerek, Budapest: Óbudai Egyetem, Bánki Donát Gépész és Biztonságtechnikai Mérnöki Kar, 2015.

[7] Wenczel E.; Ovcharov L.: Applied Problems in Probability Theory, Mir Publisher, Moscow, 1986. 